\title{
Ewa Makowska
}

Uniwersytet Mikołaja Kopernika w Toruniu

e-mail: ewa.makowska@umk.pl

\section{PLANOWANIE I KONTROLA KOSZTÓW W POLSKICH PRZEDSIĘBIORSTWACH W LATACH 1945-1950 \\ COST PLANNING AND COST CONTROL IN POLISH ENTERPRISES IN THE YEARS 1945-1950}

DOI: $10.15611 /$ pn.2018.522.09

JEL Classification: M41

Streszczenie: Celem niniejszego artykułu jest przedstawienie znaczenia kosztów oraz ich planowania i kontroli w przedsiębiorstwach w Polsce w latach 1945-1950. Zmiany ustrojowe i gospodarcze, które zachodziły w Polsce w tym okresie, miały bezpośredni wpływ na funkcjonowanie przedsiębiorstw. Realizacja planów na poziomie przedsiębiorstwa powiązana była z planem ogólnonarodowym, a nadrzędnym zadaniem wszystkich przedsiębiorstw w gospodarce planowanej była systematyczna obniżka kosztów własnych. Rachunkowości przypisywano szczególną rolę w realizacji tego zadania. Stanowiła ona źródło danych liczbowych umożliwiających planowanie i kontrolę prowadzonej działalności. Jej celem było także prowadzenie rachunku kosztów na potrzeby kalkulacji, sprawozdawczości i statystyki. Informacje generowane w systemie rachunkowości stanowiły również źródło danych wykorzystywanych dla celów poprawy funkcjonowania organizacji, koszty uważano za „zwierciadło” organizacji i działalności zakładu przemysłowego.

Słowa kluczowe: koszty, przedsiębiorstwo państwowe, planowanie i kontrola kosztów.

Summary: The purpose of this article is to present the importance of costs and their planning and control in enterprises in Poland in the years 1945-1950. The political and economic changes that took place in Poland during this period had a direct impact on the functioning of enterprises. The implementation of plans at the level of the enterprise was related to the national plan and the overriding task of all enterprises in the economy was to systematically reduce own costs. Accounting has been given a special role in the implementation of this task. It was a source of numerical data enabling planning and control of the conducted activity. Its purpose was also to conduct a cost account for the needs of calculation, reporting and statistics. Information generated in the accounting system was also a source of data used for the purposes of improving the functioning of the organization, and costs were considered as a "mirror" of the organization and operations of the industrial plant.

Keywords: costs, state enterprise, cost planning and cost control. 


\section{Wstęp}

Polska po zakończeniu działań wojennych w latach 1945-1950 wznowiła działalność z całkowicie zmienionym ustrojem społecznym, politycznym i ekonomicznym. Pierwszym wyzwaniem, przed jakim stanęła rachunkowość w okresie po II wojnie światowej, było opanowanie chaosu powojennego. W tym celu przeprowadzony został, w formie spisu z natury, wykaz pozostałych po wojnie zasobów majątkowych [Banaszkiewicz 2016, s. 181-182].

Na podstawie ustawy z dnia 3 stycznia 1946 r. [Ustawa z dnia 3 stycznia 1946] wszystkie przedsiębiorstwa państwowe o znaczeniu podstawowym dla gospodarki narodowej oraz przedsiębiorstwa przemysłowe, które zatrudniały na jedną zmianę więcej niż 50 pracowników, a także przedsiębiorstwa poniemieckie zostały przejęte przez państwo [Lulek 1948, s. 282]. Była to decyzja rzutująca na funkcjonowanie polskiej gospodarki w kolejnych dziesięcioleciach. W ten sposób pod zarząd państwa przeszło $90 \%$ wszystkich przedsiębiorstw, głównie tych mających kluczowe znaczenie z punktu widzenia państwa [Karbowiak, Kraszyna 1946, s. 95-96]. Przedsiębiorstwa państwowe miały za zadanie realizować plany gospodarcze określane przez władze centralne w sposób umożliwiający systematyczne poszerzanie stanu posiadania, przy pełnym wykorzystaniu sił produkcyjnych. W konsekwencji ich działalność przyczyniać się miała do właściwego rozdziału dochodu społecznego, a także stałego podnoszenia dochodu i dobrobytu warstw społecznych [Górniak 1949, s. 4-5].

Pod koniec 1948 r. niemal całkowitej monopolizacji uległ handel hurtowy. Coraz większy był udział państwa w handlu detalicznym. Po upływie 3,5 roku budowa demokracji ludowej na wzór sowiecki była niemal całkowicie zakończona [Davies 2006, s. 1032]. Wszystkie obszary działalności gospodarczej podlegały systemowi centralnego planowania. Rachunkowość również została podporządkowana wymogom gospodarki centralnie planowanej. Choć w powojennej Polsce podejmowano pewne próby wdrożenia zasad rozrachunku ekonomicznego, to nie przybliżały one kraju do gospodarki rynkowej [Jaruga, Kabalski 2012, s. 62].

Znaczenie, jakie przypisywano rachunkowości w przedsiębiorstwie po II wojnie światowej, a zwłaszcza w dużych zakładach, ujmowano w trzech następujących obszarach [Witkowski 1947, s. 5]:

1. Sprawozdawczość - rachunkowość, a właściwie informacje generowane w systemie księgowości stanowiły wyczerpujące i dokładne źródło danych niezbędnych dla celów sprawozdawczych o przeszłej działalności przedsiębiorstwa.

2. Kontrola - rachunkowość umożliwiała śledzenie bieżącej działalności zakładu oraz czuwanie nad jej prawidłowym przebiegiem.

3. Planowanie - rachunkowość stwarzała podstawę dla określenia przyszłej działalności przedsiębiorstwa.

Rola rachunkowości w gospodarce socjalistycznej znacznie wzrosła w momencie upaństwowienia gospodarki. Stanowiła ona element socjalistycznego rachunku 
gospodarczego, do którego zaliczano także rachunek statystyczny i rachunek operatywno-techniczny [Wojciechowski 1964, s. 14]. Do najważniejszych zadań rachunkowości należało wówczas [Wojciechowski 1952, s. 4]:

a) dostarczanie danych dla przeprowadzenia kontroli finansowej wykonania planów gospodarczych,

b) zapewnienie informacji dla potrzeb kontroli wykonania planów obniżki kosztów,

c) kontrola stanu finansowego przedsiębiorstwa i wykorzystania powierzonych mu środków,

d) kontrola i ewidencja majątku przedsiębiorstwa.

Podkreślano, iż łączenie planów przedsiębiorstw w ogólny plan całego państwa nie jest możliwe bez uporządkowanej i odpowiednio zorganizowanej rachunkowości [Witkowski 1947, s. 5]. Dlatego w okresie powojennym rachunkowość była ściśle regulowana przez wiele różnych przepisów prawnych, które podlegały częstym zmianom i uzupełnieniom [Jaruga, Szychta 1997, s. 512]. Ramy organizacyjne rachunkowości w Polsce przede wszystkim stanowiły przepisy dotyczące planów kont. Określały one kryteria klasyfikacji poszczególnych pozycji i transakcji. Plany kont zaczęto stosować w Polsce po zakończeniu II wojny światowej. Pierwszy jednolity plan kont wprowadzono z dniem 1 stycznia1946 r. dla państwowych przedsiębiorstw przemysłowych i handlowych. Zalecał on szczegółowy podział kosztów według miejsc powstawania [Wojciechowski 1948, s. 8]. Jednolity plan kont z 1946 r. zawierał wiele kont ,wolnych" i dawał pełną swobodę w zakresie pomiaru i ewidencji kosztów. Nie zapewniał tym samym jednolitości informacji tworzonych w poszczególnych przedsiębiorstwach. Z tego powodu został zreformowany w latach 1948-1949. Najważniejsze zmiany polegały na [Jaruga, Szychta 1997, s. 513]:

a) wprowadzeniu kilku jednolitych planów kont (dla przemysłu głównego, budownictwa, rolnictwa, handlu i przemysłu drobnego),

b) wprowadzeniu obowiązkowych zasad korespondencji kont,

c) położeniu nacisku na ewidencję kosztów rodzajowych.

Jednolity plan kont z 1950 r. wyeliminował zbytnią elastyczność poprzednich rozwiązań, a przede wszystkim uwzględnił wymagania ówczesnego systemu finansowego. Na podstawie jednolitych planów kont tworzone były branżowe plany kont. Według Doraczyńskiego [1974, s. 256], plany te z metodologicznego punktu widzenia były jak na tamte czasy rozwiązaniem postępowym i nowoczesnym, ponieważ umożliwiały przygotowanie różnych bilansów gospodarki narodowej oraz stanowiły punkt wyjścia do opracowania metodologii planowania gospodarczego.

Celem niniejszego artykułu jest przedstawienie istoty kosztów oraz ich znaczenia, planowania i kontroli w przedsiębiorstwach w Polsce w latach 1945-1950.

W momencie oparcia gospodarki na rozgałęzionych i skomplikowanych jednostkach przemysłowych okazało się, że stosowana do tej pory księgowość handlowa była niewystarczającym narzędziem do obsługi dużych podmiotów gospodarczych. Proponowane rozwiązania z zakresu kontroli, planowania i rachunku kosztów sta- 
nowiły prawdziwe wyzwanie dla kadry zarządzającej w przedsiębiorstwach przemysłowych. Były one pracochłonne, wymagały wykonywania licznych obliczeń rachunkowych oraz fachowej wiedzy z zakresu rachunkowości. Niestety braki kadrowe oraz słabe wykształcenie osób nowo zatrudnionych, a także braki techniczne, brak maszyn i urządzeń obliczeniowych, wykorzystywanie przestarzałych metod i technik rachunkowych uniemożliwiały szybkie wprowadzanie zmian racjonalizatorskich w przedsiębiorstwach. Z drugiej strony, przed rachunkowością stawiano wciąż nowe oczekiwania. Między innymi postulowano, że rachunkowość, przy wykorzystaniu księgowości (fabrycznej), powinna umożliwić kierownictwu przedsiębiorstwa państwowego ciągłą kontrolę jego działalności, a także stwierdzać, gdzie i w jakim zakresie można i trzeba przeprowadzić oszczędności lub gdzie kontrola winna być zaostrzona [Sowa 1950, s. 2]. Należy jednak zaznaczyć, że aby przedsiębiorstwa rzeczywiście mogły prowadzić rachunek kosztów i kalkulację fabryczną, powinny mieć pełną swobodę w zakresie podejmowania decyzji. Dlatego też z góry narzucona przez państwo cena wyrobu oraz wielkość produkcji w praktyce uniemożliwiała stosowanie wielu rozwiązań z zakresu planowania krótkookresowego w przedsiębiorstwie [Skrzywan 1948, s. 9-10].

\section{Koszty i ich znaczenie w przedsiębiorstwie w gospodarce centralnie planowanej}

Problematyka rachunkowości przedsiębiorstw przemysłowych była niezwykle różnorodna. Obejmowała ona całość procesów gospodarczych występujących w przedsiębiorstwie przemysłowym, dążąc do ustalenia jak najdokładniejszego kosztu własnego wytworzenia jednostki produktów oraz wyników, takich jak wydajność, rentowność i gospodarność przedsiębiorstwa. Oprócz systemu księgowości finansowej zwanej księgowością ogólną w ramach księgowości przemysłowej Niemski wyodrębnia następujące działy rachunkowości, nazywane działami rachunkowości pomocniczej [Niemski 1947, s. 271]:

1) rachunkowość materiałową połączoną z kontrolą wewnętrzną obrotu materiałowego,

2) rachunkowość fabryczną,

3) rachunkowość płac,

4) rachunkowość kosztów, grupującą i rozliczającą nakłady i koszty dla celów kalkulacji kosztu własnego wytworzenia jednostki produktu.

Działy te wraz z księgowością stanowily podstawę planowania gospodarczego oraz kontroli wykonania planów w przedsiębiorstwie. Była to niezwykle istotna kwestia, ponieważ w gospodarce socjalistycznej zadaniem każdego przedsiębiorstwa (a przedsiębiorstwa przemysłowego szczególnie) było „(...) wykonanie ustalonego przez czynniki nadrzędne planu produkcji pod względem asortymentu, ilości i jakości wyrobów przy najniższych kosztach. Stąd plan kosztów stanowić może miernik dla oceny wysiłków kierownictwa i całej załogi” [Skrzywan 1949, s. 33]. W związku 
z tym plan kosztów znajdował się w centrum zainteresowania rachunkowości przedsiębiorstwa, a przez to i jego kierownictwa. Skrzywan podawał następujące długości okresu planowania spotykane w literaturze przedmiotu [Skrzywan 1948, s. 44-45]:

a) okres trzyletni stanowiący plan zasadniczy w Polsce w I połowie XX wieku,

b) okres pięcioletni będący podstawą planowania głównych tendencji rozwojowych gospodarki radzieckiej,

c) okres dziesięcioletni wynikający z zaplanowanych inwestycji w przypadku dużych koncernów.

Planowanie, czyli „rachunek przyszłościowy”, w przedsiębiorstwie obejmowało najczęściej następujące kwestie [Skrzywan 1948, s. 18]: obliczanie rentowności nowo powstałego przedsiębiorstwa, kalkulację ofertową, ustalanie zapotrzebowania na kapitał. Niestety, bardzo rzadko działania te miały charakter całościowy. Najczęściej poszczególne działy rachunku gospodarczego, czyli kalkulacja, statystyka i rachunkowość, prowadzone były oddzielnie i nie stanowiły spójnej całości. Stąd kalkulacja często odbywała się poza działem księgowości (często sporządzana była przez osoby niezwiązane z działem księgowości). I odwrotnie - księgowość nie korzystała z dorobku kalkulacji. Natomiast statystyka ograniczała się do generowania informacji wymaganych dla potrzeb statystyki ogólno państwowej. Częściowo sytuację taką wyjaśnić może stan wiedzy kierownictwa przedsiębiorstwa, które najczęściej nie miało wykształcenia ekonomicznego, ponieważ wywodziło się ze sfer inżynierskich, a ich znajomość nauk ekonomicznych ograniczała się do wybranych elementów teoretycznych oraz wiedzy zdobytej w praktyce, często nie mającej nic wspólnego z nowoczesną rachunkowością [Skrzywan 1948, s. 21].

Natomiast systematyczną analizę kosztów oraz wpływu na ich wysokość wielkości produkcji uznawano za bardzo pomocne w określaniu optymalnej wielkości produkcji [Witkowski 1947, s. 126]. Skrzywan zaznacza jednak, że zagadnienie kosztów stałych i zmiennych traci na znaczeniu w warunkach gospodarki planowanej, gwarantującej przedsiębiorstwu zatrudnienie odpowiadające jego optymalnemu poziomowi zdolności produkcyjnych [Skrzywan 1948, s. 55].

Generalnie plan kosztów w przedsiębiorstwie obejmował przewidywane koszty całego przedsiębiorstwa według ich rodzaju, a więc według klasyfikacji zaproponowanej w klasie 4 jednolitego planu kont. Klasa ta zawierała wszystkie koszty pogrupowane według rodzaju, które uwzględniane były w kalkulacji kosztu wytworzenia. Zgodnie z jednolitym planem kont wprowadzonym w roku 1946, w klasie czwartej rejestrowano proste nakłady na następujących grupach kont [Kalinowski 1947, s. 20]:

40 - Materiały zużyte do wytwarzania,

41 - Robocizna i świadczenia dla robotników,

42 - Pensje i świadczenia dla pracowników umysłowych,

43 - Energia obca,

44 - Materiały zużyte na cele ogólne wytwarzania, administracji i zbytu,

45 - Podatki, daniny i opłaty publiczne (prócz podatku obrotowego i dochodowego), 
46 - Różne koszty ogólne,

47 - Odpisy i koszty kalkulowane,

48 - W (,,Wolne"),

49 - Koszty specjalne.

Celem prowadzonej ewidencji na kontach zespołu 4 było [Niemski 1947, s. 135]:

a) księgowe zarejestrowanie wszystkich kosztów dla potrzeb wewnętrznej kontroli oraz porównań i planowania ogólnego i branżowego,

b) przygotowanie materiału liczbowego dla potrzeb przeprowadzenia rachunku kosztów według miejsc powstawania i/lub wyrobów w ramach lub poza ramami księgowości.

W praktyce dla każdej planowanej pozycji kosztów istniał jej właściwy odpowiednik w księgowości przedsiębiorstwa, co umożliwiało bezpośrednie porównanie planu z rzeczywistością oraz ustalenie kwoty powstających odchyleń. Aby obliczenia te mogły stanowić podstawę dla dalszych analiz, należało jeszcze [Skrzywan 1949, s. 39-41]:

a) określić miejsca powstawania kosztów w przedsiębiorstwie,

b) przeprowadzić podział na koszty zależne i niezależne od stopnia zatrudnienia przedsiębiorstwa,

c) ustalić za jakie koszty ponosi dany dział odpowiedzialność, czyli na jakie koszty ma wpływ, względnie tego wpływu nie posiada.

Określenie miejsc powstawania kosztów w przedsiębiorstwie było istotne także z kalkulacyjnego punktu widzenia. Gromadzenie kosztów danego miejsca umożliwiało następnie porównanie ich z efektywną pracą wykonywaną przez dane miejsce. Z drugiej strony, przyczyniało się do właściwego zaliczania ponoszonych kosztów do kosztu wytworzenia poszczególnych wyrobów. W związku z tym jako minimum niezbędnych miejsc kosztów wskazywano [Witowski 1948, s. 51-52]:

1) miejsce kosztów zaopatrzenia materiałowego,

2) miejsce kosztów wytworzenia (produkcji),

3) miejsce kosztów sprzedaży.

Kosztami w znaczeniu kalkulacyjnym (w odróżnieniu od księgowego określenia nakłady) nazywano „wartość dóbr i usług, zużytych na cele właściwej wytwórczej działalności przedsiębiorstwa w określonym okresie obrachunkowym" [Witkowski 1947, s. 22]. Do kosztów produkcji zaliczano [Niemski 1947, s. 274-279]: materiały zużyte do wytwarzania, koszty specjalne, praca ludzka, ogólne koszty materiałowe, ogólne koszty wytworzenia, ogólne koszty administracji fabrycznej, ogólne koszty sprzedaży.

Mając na uwadze rzetelne prowadzenie rachunku kosztów, a szczególnie ustalanie jednostkowego kosztu wytwarzania, wyodrębniano koszty bezpośrednie i pośrednie [Skrzywan 1951, s. 34]. Grupowanie kosztów dla celów kalkulacyjnych zgodne było ze wzorem rachunku wyników, prezentowanym w jednolitym planie kont [Witkowski 1947, s. 51-52]. Dla celów kalkulacyjnych niezwykle pomocne były tak zwane arkusze rozliczeniowe lub kalkulacyjne, przy wykorzystaniu których 
następowało przeniesienie nakładów zebranych na kontach nakładów do rozliczenia na konta kosztów układu kalkulacyjnego [Skrzywan 1951, s. 77].

Jednostkowy koszt własny wyrobu stanowił punkt wyjścia dla kalkulacji poziomu ceny. Po dodaniu do niego narzutu zysku otrzymywano cenę sprzedaży netto. Doliczając do niej jeszcze specjalne koszty sprzedaży, podatek obrotowy i ewentualny podatek konsumpcyjny, uzyskiwano cenę sprzedaży brutto. Należy zaznaczyć, że przedsiębiorstwa państwowe w Polsce, które zbywały całą produkcję branżowym centralom zbytu, dokonywały sprzedaży wyrobów po tak zwanej cenie rozliczeniowej obejmującej koszt własny powiększony o narzut zysku. Przy tym nie umniejszano znaczenia kosztów normowanych, zwłaszcza dla organizacji pracy i kalkulacji fabrycznej. Podkreślano ich znaczenie zwłaszcza w systemie kontroli, którego efektywność przekładała się na poprawę organizacji rachunkowości fabrycznej i dokładność uzyskiwanych wyników.

Zdaniem Niemskiego: „Racjonalna kalkulacja kosztów własnych powinna być oparta na kosztach wzorcowych". Koszty wzorcowe, nazywane też normatywnymi, definiowano jako preliminowane na przyszły okres gospodarczy szacunkowe normy kosztów własnych tak ustalone, by zapewniały optymalną wydajność i rentowność przedsiębiorstwa przy danym stanie urządzeń wytwórczych i warunków rynkowych” [Niemski 1947, s. 303-304]. Stosowanie kosztów wzorcowych umożliwiało bieżące prowadzenie rachunku kosztów oraz wykrywanie powstających nieprawidłowości na bieżąco. Analiza odchyleń kosztów rzeczywistych od wzorcowych odbywała się [Fedak 1949a, s. 34-35]: w ramach prowadzonej księgowości, pozaksięgowo (statystycznie) lub według metody kompromisowej.

Plan kosztów oparty na kosztach wzorcowych zdaniem Skrzywana był udoskonaleniem metod planowania w ogóle. Był on jednak możliwy do zastosowania w przedsiębiorstwach większych, doskonale zorganizowanych i dysponujących odpowiednim personelem [Skrzywan 1948, s. 49].

W gospodarce centralnie planowanej znaczenie i wykorzystanie rachunkowości w przedsiębiorstwie zdaniem Skrzywana było dużo większe niż w państwach kapitalistycznych. Do najważniejszych wyróżników wskazywanych przez niego należy zaliczyć następujące kwestie [Skrzywan 1948, s. 40-41]:

1. Zasięg planowania - w gospodarce socjalistycznej planują wszystkie przedsiębiorstwa, podczas gdy w gospodarce kapitalistycznej tylko nieliczne, najczęściej duże jednostki przemysłowe.

2. Dysponowanie szerokim materiałem porównawczym i możliwość przeprowadzenia różnorodnych porównań branżowych i międzybranżowych, co w gospodarce kapitalistycznej możliwe jest do przeprowadzenia tylko w przypadku koncernów.

3. Stosowanie jednolitych norm technicznych i gospodarczych w obrębie danej branży umożliwia sporządzanie dowolnych statystyk gospodarczych - wprowadzanie ujednoliceń w krajach kapitalistycznych jest dość utrudnione.

4. Kontrola wykonania planu była tożsama z kontrolą wykorzystania uspołecznionych środków produkcji, a więc funkcją niezwykle ważną z punktu widzenia 
dobra ogólnego. Kontrola taka z powodów ustrojowych nie była w związku z tym możliwa w państwach kapitalistycznych.

Informacje generowane w systemie rachunkowości stanowiły także źródło danych wykorzystywanych dla celów poprawy funkcjonowania organizacji. Koszty, które stanowiły jeden z obszarów ewidencji prowadzonej w przedsiębiorstwie przez księgowość, uważano za „zwierciadło” organizacji i działalności zakładu przemysłowego [Witkowski 1947, s. 116].

Na uwagę zasługuje fakt, że w okresie powojennym przykładano bardzo dużą wagę do psychologicznego wymiaru planowania i kontroli. Na przykład Skrzywan zauważa znaczenie poczucia odpowiedzialności indywidualnego pracownika za opracowany plan oraz wkład w jego realizację z perspektywy całego przedsiębiorstwa. W związku z tym podkreśla on znaczenie planowania oddolnego, wynikającego z inicjatywy najdrobniejszych komórek, w przeciwieństwie do planów z góry narzuconych do realizacji, które utrudniają identyfikację odpowiedzialności za przygotowany plan [Skrzywan 1948, s. 43].

\section{Kontrola kosztów w przedsiębiorstwie}

Rola i zakres kontroli w przedsiębiorstwie uspołecznionym były bardzo duże. Skrzywan zdefiniował je następująco: „Kontrola, jeżeli ma być efektywna, jeżeli ma być podstawą wnioskowania kierownictwa, powinna działać stale, szybko i dokładnie, powinna dotyczyć zadań nie tylko ogólnych, ale - i to przede wszystkim - zagadnień szczegółowych, detali pracy przedsiębiorstwa [Skrzywan 1948, s. 75].

Kontrola działalności przedsiębiorstwa oprócz zakresu formalnego i merytorycznego spełniała wiele zadań szczegółowych, takich jak analiza uzyskiwanych informacji, porównanie planu i jego wykonania, wyjaśnianie przyczyn powstałych odchyleń oraz ośrodków za nie odpowiedzialnych. Należy podkreślić fakt, że lokalizację odchyleń oraz określenie rodzaju odchyleń za które odpowiadał dany dział, uważano za warunek konieczny prowadzenia racjonalnej organizacji oraz powodzenia gospodarki planowej w przedsiębiorstwie [Skrzywan 1948, s. 74].

Planowanie wymaga wyraźnego sformułowania celu głównego, a następnie rozłożenia go na elementy składowe, czyli zadania do zrealizowania. Dlatego z punktu widzenia gospodarki centralnie sterowanej w trakcie procesu planowania na poziomie przedsiębiorstwa następowało zharmonizowanie jego celów z celami gospodarki narodowej. Powiązanie planowania na poziomie przedsiębiorstwa z planami w ujęciu ogólnonarodowym teoretycznie miało umożliwić uzyskanie rezultatów niespotykanych dotychczas w gospodarce. Przejawiać miały się one w dwóch podstawowych obszarach, to jest równomiernym zatrudnieniu w przedsiębiorstwie oraz optymalnym wykorzystaniu zdolności produkcyjnych, zapewniających minimalne koszty produkcji. Dokładne określenie zadań do wykonania oraz wymaganych na ich realizację nakładów stwarzało także bardzo dobrą podstawę dla kontroli działalności prowadzonej przez przedsiębiorstwo [Skrzywan 1948, s 42-43]. 
Jaruga wskazywała na możliwość wykorzystania kontroli kosztów od budowy preliminarza budżetowego oraz podkreślała przydatność z punktu widzenia budżetowej kontroli kosztów, „(...) zapewnienia podziału kosztów danego miejsca (czy funkcji) na pozycje analityczne w zależności od stopnia ich zmienności” [Jaruga 1966, s. 207-208]. Pod koniec lat 40. XX wieku propozycja wykorzystania w praktyce planowania różnych stopni zatrudnienia przy tworzeniu planów kosztów pośrednich uznawana była za niezwykle postępową. Stosowanie elastycznego budżetu pozwalało na planowanie kosztów z uwzględnieniem różnych stopni wykorzystania zdolności wytwórczej danego miejsca powstawania kosztów, mierzonej w stosunku do jego praktycznej mocy wytwórczej, przyjętej za 100 [Fedak 1949b, s. 108].

Kontrola działalności umożliwiała kierownictwu ocenę wyników prowadzonej działalności dzięki porównaniu ich z wielkościami planowanymi. Kontrola taka, w tym również danych liczbowych w rachunku kosztów, napotykała liczne trudności, między innymi związane z eliminowaniem wpływu zmiany siły nabywczej pieniądza. Z powodu olbrzymiego nakładu pracy wynikającej z wykonania takich prac $\mathrm{w}$ praktyce stosowano najczęściej ,zasadnicze lub częściowe przeliczanie bilansów" [Skrzywan 1948, s. 81]. Dlatego z punktu widzenia dokonywania porównań czy też wnioskowania przeprowadzanego na ich podstawie podkreślano znaczenie wprowadzania w gospodarce planowanej centralnie cen rozliczeniowych oraz cen i kosztów planowanych i normowanych. Drugą kwestią była częstotliwość dokonywanych kontroli. W warunkach częstych i znacznych zmian w warunkach gospodarczych wskazana była kontrola okresów krótkich, umożliwiających porównywanie analizowanych danych.

Nowym wyzwaniem w gospodarce centralnie planowanej, z punktu widzenia kontroli, były porównania międzyzakładowe dokonywane na terenie zjednoczeń, dyrekcji branżowych lub centralnych zarządów (na poziomie całych gałęzi przemysłu), związane bezpośrednio z organizacją przemysłu uspołecznionego. Kontrola taka była możliwa dzięki stosowaniu przez przedsiębiorstwa uspołecznione jednolitych przepisów w zakresie [Skrzywan 1948, s. 82]:

a) planu kont,

b) klasyfikacji materiału liczbowego,

c) sprawozdawczości szczegółowej,

d) wartościowania w bilansach i w rachunku kosztów,

e) okresów rozrachunkowych.

Porównania międzyzakładowe w zakresie kosztów miały na celu: wskazanie najbardziej ekonomicznych metod lub organizacji produkcji czy określenia stopnia wykorzystania zdolności wytwórczych zakładów. Porównania takie mogły opierać się na danych zarówno rzeczywistych, jak i planowanych.

To właśnie dzięki gospodarce centralnie sterowanej zakres i użyteczność kontroli teoretycznie miały osiągnąć wartość optymalną. Przede wszystkim wynikało to z zakresu kontroli, która obejmowała swym zasięgiem różnorodne obszary funkcjonowania przedsiębiorstwa. Zestawienia $\mathrm{i}$ analizy uzyskanych wyników w różnych 
przekrojach i obszarach działalności, a następnie porównanie ich z planem miało zagwarantować uzyskanie jednoznacznych wskazań w zakresie stopnia wykonania planów, które to przekładały się między innymi na ocenę rentowności przedsiębiorstwa oraz efektywności wykorzystania posiadanych zasobów.

\section{Podsumowanie}

Na podstawie przeprowadzonych badań literaturowych można sformułować następujące wnioski:

1. Rachunkowość w Polsce w okresie po II wojnie światowej stanowiła, obok rachunku statystycznego i operatywno-technicznego, element socjalistycznego rozrachunku gospodarczego.

2. Oprócz ewidencji księgowej podstawowym celem rachunkowości było prowadzenie rachunku kosztów na potrzeby kontroli oraz sprawozdawczości finansowej i statystyki państwowej.

3. Z punktu widzenia rachunku kosztów podstawowym zadaniem kalkulacji było ustalenie kosztów wytworzenia produktów, zaksięgowanie rozliczonych kosztów oraz sporządzenie zamknięć rachunkowych dla celów sprawozdawczych.

4. Dane generowane przez rachunkowość były wykorzystywane głównie dla celów kontrolnych. Dzięki nim kierownictwo przedsiębiorstwa miało możliwość udoskonalenia organizacji jednostki w sposób zapewniający zmniejszenie kosztów i zwiększenie wydajności.

5. Kontrola kosztów działalności przedsiębiorstwa, oprócz zakresu formalnego i merytorycznego, spełniała wiele zadań szczegółowych, takich jak: analiza uzyskiwanych informacji, porównanie planu i jego wykonania, wyjaśnianie przyczyn powstałych odchyleń oraz ośrodków za nie odpowiedzialnych. W tym obszarze za niezwykle przydatne uważano wykorzystywanie do planowania kosztów wzorcowych.

6. Nowym wyzwaniem w gospodarce centralnie planowanej z punktu widzenia kontroli były porównania międzyzakładowe. Miały one na celu: wskazanie najbardziej ekonomicznych metod lub organizacji produkcji oraz określenie stopnia wykorzystania zdolności wytwórczych zakładów.

\section{Literatura}

Banaszkiewicz A., 2016, Charakterystyka rachunkowości przedsiębiorstw państwowych $w$ Polsce w latach 40. i 50. XX wieku, [w:] Abacus - od instruktarzy gospodarczych po wspótczesne podręczniki rachunkowości, S. Sojak (red.), Wydawnictwo Naukowe Uniwersytetu Mikołaja Kopernika, Torun.

Davies N., 2006, Boże igrzysko. Historia Polski, Wydawnictwo Znak, Kraków.

Doraczyński J., 1974, Rozwój planów kont w PRL, Rachunkowość, nr 7.

Fedak Z., 1949a, Koszty wzorcowe, Przegląd Organizacji, nr 1.

Fedak Z., 1949b, Elastyczny plan kosztów pośrednich, Przegląd Organizacji, nr 3. 
Górniak S., 1949, Zasady teorii księgowości oraz techniki księgowania i bilansowania, Instytut Wiedzy, Spółdzielnia Wydawnicza Autorów w Gliwicach, Gliwice.

Jaruga A., 1966, Koszty zarządzania przedsiębiorstw przemysłowych, PWE, Warszawa.

Jaruga A., Kabalski P., 2012, Od niemieckich ksiag handlowych do Międzynarodowych Standardów Rachunkowości. Zarys historii regulacji rachunkowości w Polsce, [w:] Wspótczesne nurty badawcze w rachunkowości, I. Sobańska, P. Kabalski (red.), Wydawnictwo Uniwersytetu Łódzkiego, Łódź.

Jaruga A., Szychta A., 1997, The origin and evolution of charts of accounts in Poland, The European Accounting Review, vol. 6, no. 3.

Kalinowski A., 1947, Księgowość i kalkulacja przemysłowa na tle Jednolitego Planu Kont, Skład główny: Księgarnia Spółdz. Wyd. „Czytelnik”, Katowice.

Karbowiak T., Kraszyna F., 1946, Księgowość jednostek gospodarczych związkowych, część II, Nakładem Kursów Handlowych, Chorzów.

Lulek T., 1948, Handel i przedsiębiorstwo handlowe (kupieckie i spółdzielcze), Wydawnictwo „Nauka", Kraków.

Niemski K., 1947, Teoria i technika księgowości przedsiębiorstw, Spółdzielnia Wydawnicza „Książka”, Warszawa.

Skrzywan S., 1948, Rachunkowość w przedsiębiorstwie przy gospodarce planowanej, Gospodarczy Instytut Wydawniczy Sp. z o.o. Izb Przemysłowo-Handlowych i Rady Naczelnej Zrzeszeń Kupieckich R. P., Warszawa.

Skrzywan S., 1949, Kontrola w przedsiębiorstwie, Trzaska, Evert i Michalski, Warszawa.

Skrzywan S., 1951, Rachunkowość w przemyśle, Część II, PWN, Warszawa.

Sowa K., 1950, Księgowość przedsiębiorstw przemysłowych, Akademia Handlowa w Krakowie, Państwowe Zakłady Wydawnictw Szkolnych, Kraków.

Ustawa z dnia 3 stycznia 1946 r. o przejęciu na własność państwa podstawowych gałęzi gospodarki narodowej, Dz. U. R. P. nr 3, poz. 17.

Witkowski Z., 1947, Zasady księgowości i kalkulacji fabrycznej, Księgarnia Wł. Wilak w Poznaniu, Poznań.

Witowski J., 1948, Obliczanie kosztów własnych, Księgarnia Wł. Wilak w Poznaniu, Poznań.

Wojciechowski E., 1948, Księgowość i kalkulacja w oparciu o jednolity plan kont, W. Nagłowski i S-ka, Częstochowa.

Wojciechowski E., 1952, Wiadomości wstępne: ogólna charakterystyka funkcji przedsiębiorstw przemysłowych, G.I.W., Warszawa.

Wojciechowski E., 1964, Zarys rozwoju rachunkowości w dawnej Polsce, PWN, Warszawa. 